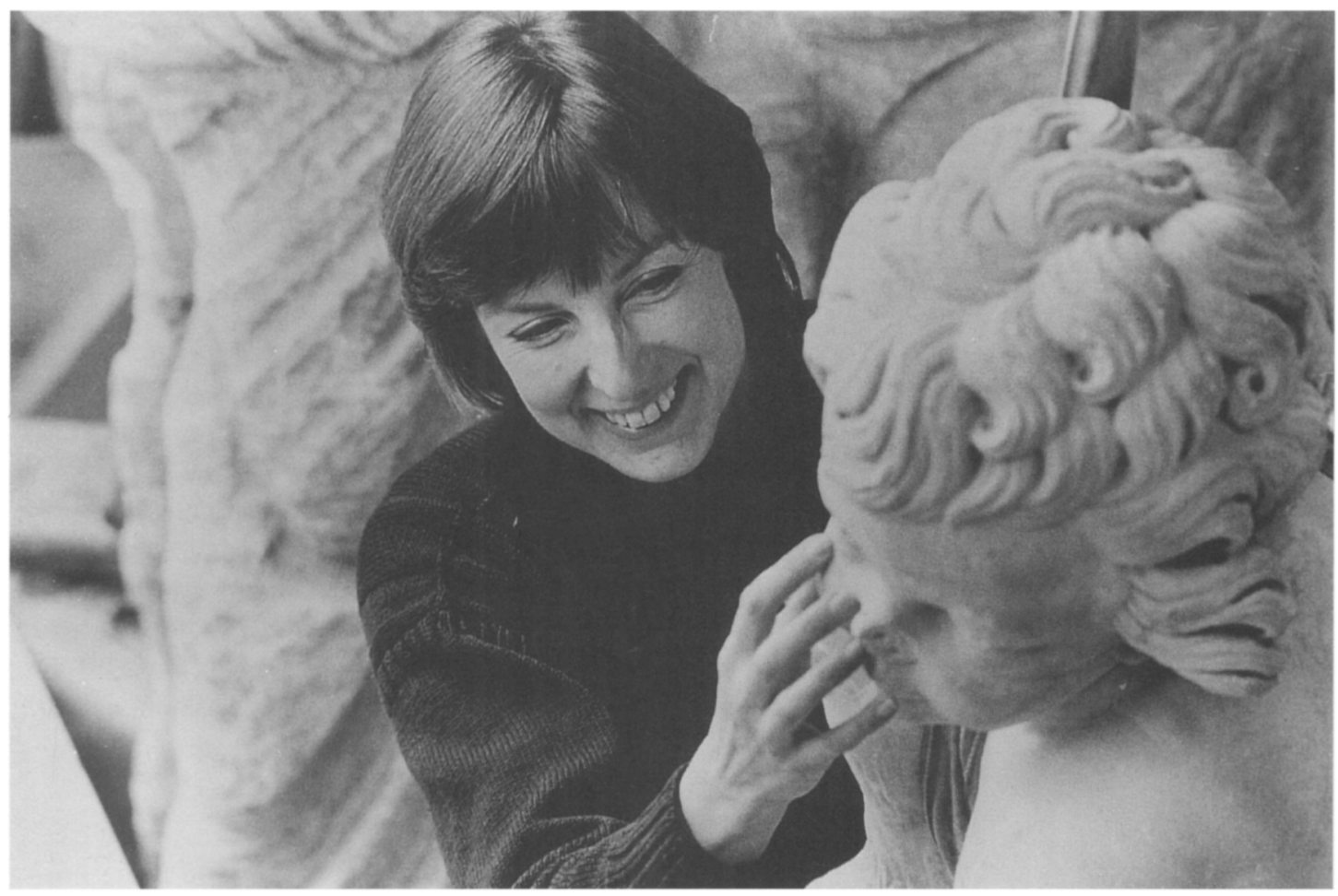

\title{
THE HON. ANNA PLOWDEN CBE
}

$$
\text { 1938-1997 }
$$

Anna was born into a formidably clever and ancient Shropshire family, the eldest of four children of Edwin and Bridget Plowden. She went to New Hall near the family home at Dunmow, Essex and then to the Institute of Archaeology of London University. After graduating with a Diploma in Conservation, she was awarded a bursary by the British School of Archaeology in Iraq to piece together and restore the Nimrud Ivories excavated in Rooms SW37 and T10 of Fort Shalmaneser. My wife and I met her in Baghdad in 1964 while she was tackling this monumental task. She seemed delicate, a gamine but porcelain figure in the tough Iraqi setting. She soon caught hepatitis, recovering slowly while dozens of Iraqi and other friends vied to take her grapes. It was a time of revolutions, pro or anti-Baath Party, every six or nine months. Her family needed reassurance that Anna would be all right. We never had the slightest doubt.

When she returned to England, Anna set up in business with Peter Smith in 1965 to restore antiquities, tackling in due course items from all civilisations and learning more and more as they went. She once told me that Norton Simon, the noted American collector, had sent her a lot of bronzes, some of them "almost gone". He remained a customer for many years. To illustrate the breadth of her range, she restored for us three Imperial Chinese silk chair covers, and then mounted them in perspex as an experiment since they were long and unwieldly. They look down on me now as I write. She also cleaned and mounted for us an awkward basalt torso found at Khajuraho. Anna could, in truth, mend practically anything. The older and rarer it was, the more trouble she took, and I suspect that she habitually undercharged the poorer customer.

In 1990 Anna was elected a Life Member of the Council of the BSAI, since she was the greatniece of Gertrude Bell (whose Memorial the School of course is) and still closely interested in all the School's activities. When the School's statute was revised in 1996, Council decided to put Anna's name forward to the Annual General Meeting of December 1997 for nomination as a Vice-President. Had we known how ill she already was, we would have acted to forestall the grim 
reaper. But it seemed fitting that in January 1997 Anna was awarded the same high decoration as Gertrude Bell, the CBE. Anna's honour was for services to conservation, especially in British museums. Bell's citation eighty years earlier would have been somewhat different, but she too became a leading conservationist towards the end. Bell died aged 58, Anna lived one year longer. Both were remarkable women, but I like to think that Anna died the happier one, brave but puzzled by her untimely fate.

STEPHEN EgERTON

Photograph by Sue Adler (1983) reproduced courtesy of the Observer. 